\title{
PENINGKATAN KOMPETENSI STRATEGIS MATEMATIS SISWA SEKOLAH MENENGAH KEJURUAN (SMK) MELALUI STRATEGI TEAM-BASED LEARNING
}

\author{
Oleh: \\ ${ }^{1)}$ Krisyanti Amalia, ${ }^{2)}$ Darhim, ${ }^{3)}$ Bambang Avip Priatna M. \\ ${ }^{1,2,3)}$ Departemen Pendidikan Matematika SPs Universitas Pendidikan Indonesia \\ ${ }^{1}$ krisyanti_amalia@ymail.com
}

\begin{abstract}
ABSTRAK
Penelitian ini bertujuan untuk menelaah pengaruh strategi team-based learning terhadap peningkatan kompetensi strategis matematis siswa SMK Informatika baik ditinjau secara keseluruhan maupun berdasarkan kategori pengetahuan awal matematika (PAM). Penelitian ini merupakan penelitian kuasi eksperimen dengan desain kelompok kontrol non-ekivalen yang melibatkan 139 siswa kelas X. Instrumen yang digunakan adalah tes kompetensi strategis matematis. Analisis statistik yang dilakukan adalah Independent Samples t-test, Mann Whitney.Hasil penelitian yang diperoleh adalah peningkatan kompetensi strategis matematis siswa yang memperoleh pembelajaran dengan strategi team-based learning lebih tinggi daripada siswa yang memperoleh pembelajaran biasa ditinjau dari keseluruhan siswa danuntuk kategori pengetahuan awal matematika sedang dan rendah.
\end{abstract}

Kata Kunci : kompetensi strategis matematis, team-based learning (TBL)

\begin{abstract}
The purpose of this study was to analyze the influence of team-based learning's strategy for the improvement of mathematical strategic competence of informatics vocational high school's students either it was reviewed on the whole or based on the the mathematics' prior knowledge (PAM). This study was a quasi-experimental research with the design of non-equivalent control group involving 139 students of class $X$. The instrument used was a test of mathematical strategic. The statistical analysis performed were independent samples t-test, Mann-Whitney test. The research results obtained arethe improvement of mathematical strategic competence of students who get team-based learning's strategy is higher than students who get usual learning reviewed on the whole students in medium and low level of prior knowledge of mathematics.
\end{abstract}

Keywords: mathematical strategic competence, team-based learning (TBL)

\section{PENDAHULUAN}

Pemerintah Indonesia telah menyadari pentingnya pendidikan bagi kemajuan Negara. Oleh karenanya, pemerintah mengambil kebijakan program wajib belajar 12 tahun atau setara Sekolah Menengah Atas (SMA) dan sederajat, bahkan beberapa pemerintah daerah telah membebaskan biaya hingga jenjang yang diwajibkan tersebut. Meskipun demikian, pendidikan untuk jenjang yang lebih tinggi lagi yaitu setara perguruan tinggi masih menjadi barang yang mahal bagi sebagian warga Negara Indonesia yang memliki tingkat ekonomi menengah. Akibatnya, warga lebih meminati pendidikan formal Sekolah Menengah Kejuruan (SMK) sebagai cara alternatif untuk mendapatkan pendidikan yang mencukupi dan mempermudah dalam mendapatkan pekerjaan. 
Program studi di SMK yang paling diminati saat ini adalah teknik informatika. Pada program studi ini, siswa dituntut untuk memiliki kemampuan berpikir logis, analitis, sistematis, kritis, dan kreatif, serta kemampuan bekerjasama. Kemampuan tersebut dapat dikembangkan melalui kegiatan pembelajaran matematika karena tujuan pembelajaran matematika di SMK di antaranya, memecahkan masalah yang meliputi kemampuan memahami masalah, merancang model matematika, menyelesaikan model dan menafsirkan solusi yang diperoleh. Siswa harus memiliki kecakapan dalam melakukan kegiatan matematika untuk mencapai kemampuan-kemampuan tersebut yang disebut dengan kecakapan matematis.

Tujuan pembelajaran matematika sejalan dengan salah satu komponen (strand) kecakapan matematis yaitu kompetensi strategis. Menurut Kilpatrick et.al (2001:116), kecakapan matematis memiliki lima komponen (strand), antara lain.

1) Pemahaman konseptual (conceptual understanding) yaitu pemahaman siswa tentang konsep-konsep, operasi-operasi dan relasi-relasi matematis.

2) Kelancaran prosedural (procedural fluency) yaitu keahlian siswa dalam menggunakan prosedur-prosedur secara fleksibel, akurat, efisien dan tepat.

3) Kompetensi strategis (strategic competence) yaitu kemampuan siswa untuk merumuskan, menyajikan, dan memecahkan permasalahan matematis.

4) Penalaran adaptif (adaptive reasoning) yaitu kapasitas siswa untuk berpikir logis, memperkirakan, merefleksikan, menjelaskan dan memberikan alasan.

5) Disposisi produktif (productive disposition) yaitu kecenderungan siswa untuk membiasakan diri melihat matematika sebagai sesuatu yang masuk akal, berguna, dan berharga, bersamaan dengan kepercayaan mereka terhadap ketekunan dan keberhasilan dirinya sendiri dalam matematika.

PISA (Programme for International Student Assessment)merupakan suatu penilaian secara internasional terhadap keterampilan dan kemampuan siswa usia 15 tahun atau setara siswa SMK. Hasil pencapaian siswa Indonesia sangat kurang memuaskan. Pada tahun 2012, menurut Indonesia Pisa Center peringkat Indonesia pada bidang matematika turun menjadi 64 dari 65 Negara peserta. Turun 3 peringkat dari pencapaian pada tahun 2009, yaitu peringkat 61 . Beberapa faktor penyebab rendahnya prestasi siswa Indonesia dalam PISA yang dikemukakan, antara lain.

1) Lemahnya kemampuan pemecahan masalah non-rutin atau level tinggi. Soal yang diujikan dalam PISA terdiri atas 6 level (level 1 terendah dan level 6 tertinggi) dan soalsoal yang diujikan merupakan soal kontekstual, permasalahannya diambil dari dunia nyata. Siswa di Indonesia hanya terbiasa dengan soal-soal rutin pada level 1 dan level 2.

2) Sistem evaluasi di Indonesia yang masih menggunakan soal level rendah. Lemahnya kemampuan pemecahan masalah juga dipengaruhi oleh sistem evaluasi di Indonesia. Baik tes yang dilakukan oleh guru ataupun pemerintah (Ujian Nasional atau UN), biasanya hanya menggunakan level 1 dan level 2. Akibatnya, siswa Indonesia tidak mampu menjangkau soal-soal level tinggi.

3) Siswa terbiasa memperoleh dan menggunakan pengetahuan matematika formal di kelas dalam proses belajar-mengajar. Pada umumnya guru biasanya memberikan rumus formal. Berbeda halnya dengan soal PISA yang diawali dengan permasalah sehari-hari, kemudian dari permasalahan tersebut siswa diminta untuk berpikir dengan bebas menggunakan berbagai cara untuk menyelesaikannya, belajar memberi alasan, belajar membuat kesimpulan, dan belajar menggeneralisasi formula atau membuat rumus umum dari permasalahan yang diberikan. 
Hasil PISA menunjukkan bahwa kemampuan pemecahan masalah yang merujuk pada kompetensi strategis matematis siswa masih kurang. Oleh karena itu, kompetensi strategis matematis siswa perlu ditingkatkan.

Seiring dengan banyaknya peminat SMK, maka siswa yang ditampung akan semakin banyak. Akibatnya, jumlah siswa dalam satu kelas cukup banyak dan proses belajar-mengajar biasa menjadi kurang efektif. Guru mengalami kesulitan, baik dalam menyampaikan materi pelajaran maupun mengidentifikasi masalah yang dihadapi siswa.

Dalam rangka mengatasi keterbatasan pembelajaran biasa pada kelas besar, maka diperlukan strategi belajar yang berbeda. Salah satu strategi belajar yang mendukung pembelajaran aktif, yaitu pembelajaran kelompok. Pembelajaran kelompok yang efektif untuk diterapkan dalam kelas besar adalah srategi team-based learning.

Team-based learning adalah suatu strategi pembelajaran di mana siswa dibagi dalam grupgrup kohesif yang terdiri atas 5-7 orang, dan mereka diharuskan bekerja secara kelompok, berdiskusi dan memecahkan masalah yang diberikan. Menurut Michaelsen \& Sweet (2008: 8), strategiteam-based learning memiliki empat unsur dasar yaitu 1) grup atau tim; grup harus dibentuk dan dikelola dengan baik, 2) tanggung jawab; siswa harus bertanggung jawab atas kualitas pekerjaan individu dan pekerjaan grup, 3) timbal balik; siswa harus sering menerima timbal balik dan tepat pada waktunya, serta 4) desain tugas; desain tugas grup harus meningkatkan pembelajaran dan perkembangan tim.

Pengelompokan siswa dalam suatu grup atau tim harus dilakukan secara tepat agar tujuan pembelajaran dapat tercapai. Oleh karena itu, tim dalam strategi team-based learning harus dirancang sedemikian rupa sehingga terdapat keheterogenan pengetahuan yang dimiliki siswa. Dalam strategi team-based learning siswa akan belajar lebih mandiri, dengan saling bertukar informasi antar sesama anggota tim lainnya. Dengan demikian, pengetahuan awal matematika siswa merupakan salah satu faktor penting dalam menerapkan strategi team-based learning. Hal ini sejalan dengan pendapat Arends (2008: 268) yang mengemukakan bahwa pengetahuan awal yang dimiliki siswa dan struktur kognitif yang sudah ada dapat mempengaruhi pemroresan informasi dan ide-ide baru yang akan dipelajari. Guru harus mempersiapkan sistem pengajaran dengan memperhatikan materi prasyarat atau pengetahuan awal matematika yang dapat menunjang proses pemahaman materi yang disajikan.

Pengetahuan awal matematika yang dimiliki oleh siswa berbeda satu sama lain, maka perlakuan pembelajaran yang diberikan akan berpengaruh terhadap respon, cara berpikir atau hasil belajar siswa. Semakin lengkap pengetahuan awal yang dimiliki, semakin mudah baginya untuk memproses informasi baru dan untuk melihat lebih banyak hubungan abstrak. Selanjutnya, pengetahuan awal matematika siswa digunakan sebagai dasar pembentukan tim. Oleh karena itu, dalam melihat peningkatan hasil belajar siswa, pengetahuan awal matematika yang terdiri dari kelompok tinggi, sedang dan rendah perlu diperhatikan setelah mengikuti pembelajaran matematika.

Tahapan-tahapan kegiatan belajar-mengajar menggunakan strategi team-based learningmenurut Michaelsen\&Sweet (2008: 12-20) diuraikan dalam tahap preparation, readiness assurance, application of course concepts yang disajikan pada gambar berikut. 


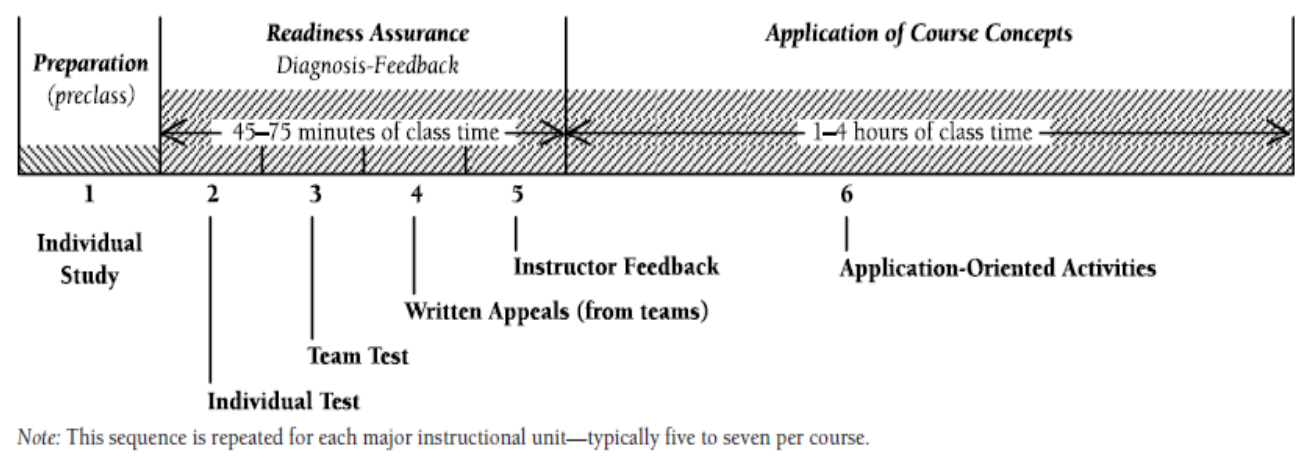

\section{Gambar 1 Rangkaian Waktu Kegiatan Instruksional Team Learning}

\section{a. Preparation}

Pada tahapan ini disajikan suatu konsep kepada siswa melalui modul pembelajaran yang berisi materi yang akan dipelajari selama proses pembelajaran. Siswa diberi tugas membaca dan mempelajari modul tersebut terlebih dahulu sebagai persiapan menghadapi proses belajar selanjutnya.

\section{b. Readiness assurance}

Pada tahapan ini guru atau fasilitator mememiksa kesiapan siswa dengan memberi tes yang berkaitan dengan tugas membaca.Kunci utama keberhasilan pelaksanaan strategi team-based learning, adalah Readiness Assurance Process (RAP). RAP memiliki lima komponen utama, yaitu.

1) Assigned readings, siswa diperkenalkan terhadap suatu konsep melalui assigned readings.

2) Individual test. Pembukaan tambahan selama tes individu membantu menguatkan memori siswa tentang apa yang mereka pelajari selama studi individu mereka.

3) Team test. Selama tes tim, siswa secara lisan mengelaborasi alasan dari pilihan jawaban mereka.

4) Appeals process. Selama proses ini siswa diberi kesempatan untuk memperbaiki nilai untuk pertanyaan yang tertinggal pada tes tim dengan menjawab pertanyaan yang tertinggal dengan benar secara tertulis. Karena siswa memiliki kesempatan untuk meningkatkan skor mereka, siswa sangat dimotivasi untuk belajar kembali yang difokuskan pada konsep yang menyulitkan mereka.

5) Instructor feedback. Guru memberi timbal balik/pengajaran perbaikan khususnya yang ditujukan pada pemecahan beberapa pemahaman yang salah yang tersisa setelah siswa menyelesaikan reviu yang difokuskan pada persiapan siswa dalam mengerjakan pertanyaan yang tertinggal pada saat tes tim.

\section{c. Application of course concepts}

Pada tahapan ini siswa diberi kegiatan yang berorientasi pada penerapan konsep. Siswa mendiskusikan masalah yang diberikan dalam bentuk lembar kerja siswa bersama-sama dengan anggota tim lainnya. Pada akhir pembelajaran, guru perlu mengingatkan siswa tentang apa yang harus mereka pelajari dari kegiatan belajar dalam sebuah tim, antara lain konsep pelajaran, penerapan konsep pelajaran, keberartian sebuah tim dalam menyelesaikan tantangan-tantangan intelektual, serta macam-macam interaksi yang dapat meningkatkan efektifitas kerja tim, dan diri siswa itu sendiri. 
Berdasarkan uraian di atas, tujuan penelitian ini adalah untuk menelaah peningkatan kompetensi strategis matematis siswa yang memperoleh pembelajaran dengan strategi teambased learningdan siswa yang memperoleh pembelajaran biasa ditinjau dari keseluruhan siswa, dan berdasarkan kategori PAM.

\section{METODE PENELITIAN}

Penelitian ini merupakanpenelitian kuasi eksperimen yang menerapkan TBL untuk meningkatkan kompetensi strategis matematis siswa SMK.Penelitian ini melibatkan dua kelas yaitu kelas eksperimen (kelas perlakuan) dan kelas kontrol (kelas pembanding). Kelas eksperimen (kelas perlakuan) merupakan kelompok siswa yang pembelajarannya menggunakan strategi team-based learning sedangkan kelas kontrol (kelas pembanding) adalah kelompok siswa yang pembelajarannya menggunakan pembelajaran biasa. Desain penelitian ini adalah desain kelompok kontrol non-ekivalen. Pada desain ini, subyek penelitian tidak dikelompokkan secara acak. Kelas yang ada sudah terbentuk sebelumnya dan pembentukan kelas baru yang dilakukan secara acak tidak mungkin dilakukan karena dapat mengganggu jadwal pelajaran dan efektifitas pembelajaran di sekolah. Dalam penelitian ini dilibatkan faktor pengetahuan awal matematis (PAM) siswa yang terdiri atas kelompok siswa yang memiliki kemampuan tinggi, sedang danrendah.

Populasi dalam penelitian ini adalah seluruh siswa SMK 4 LPPM RI Padalarang kelompok Teknologi. Siswa SMK 4 LPPM RI Padalarang kelompok Teknologi terdiri dari 14 kelas, yang pembentukan kelasnya dilakukan secara acak oleh sekolah. Selanjutnya dipilih empat kelas yang setiap kelasnya memiliki karakteristik yang sama, untuk dijadikan sampel penelitian. Sampel yang dipilih adalah siswa kelas X jurusan Teknik Komputer Jaringan (TKJ) serta siswa kelas X jurusan Rekayasa Perangkat Lunak (RPL) dengan jumlah seluruhnya 139 siswa. Instrumen yang digunakan pada penelitian ini adalah seperangkat soal tes untuk mengukur kompetensi strategis matematis siswa.

Data yang diperoleh dari penelitian ini adalah data kuantitatifyaitu analisis terhadap jawaban siswa pada soal tes kompetensi strategis matematis siswadan diolah dengan bantuan program Microsoft Excel dan software SPSS Versi 18.0 for Windows.

\section{HASIL PENELITIAN DAN PEMBAHASAN}

\section{A. Hasil Penelitian}

Banyaknya siswa yang berada pada kelompok tinggi, sedang dan rendah pada kelas eksperimen dan kontrol disajikan pada Tabel 1.

\section{Tabel 1}

Jumlah Siswa Berdasarkan PAM

\begin{tabular}{ccc}
\hline PAM & $\begin{array}{c}\text { Eksperimen } \\
\text { (TBL) }\end{array}$ & $\begin{array}{c}\text { Kontrol } \\
\text { (Biasa) }\end{array}$ \\
\hline Tinggi & 11 & 12 \\
Sedang & 53 & 44 \\
Rendah & 9 & 10 \\
\hline Total & 73 & 66 \\
\hline
\end{tabular}




\section{Statistik Deskriptif}

Tabel 2

Statisitik Deskriptif Kompetensi Strategis Matematis

\begin{tabular}{clccccccc}
\hline \multirow{2}{*}{ KELAS } & \multirow{2}{*}{ PAM } & \multirow{2}{*}{$\mathbf{N}$} & \multicolumn{2}{c}{ PRETES } & \multicolumn{2}{c}{ POSTES } & \multicolumn{2}{c}{$\langle\mathbf{g}\rangle$} \\
\cline { 5 - 10 } & & & $\overline{\boldsymbol{x}}$ & SB & $\overline{\boldsymbol{x}}$ & SB & $\overline{\boldsymbol{x}}$ & SB \\
\hline \multirow{3}{*}{$\begin{array}{c}\text { Eksperimen (Team } \\
\text { based Learning) }\end{array}$} & Tinggi & 11 & 3,09 & 1,04 & 11,36 & 1,69 & 0,64 & 0,14 \\
& Redang & 53 & 2,94 & 1,12 & 11,21 & 1,74 & 0,62 & 0,13 \\
& Kendah & 9 & 3,11 & 0,60 & 10,89 & 1,45 & 0,60 & 0,11 \\
Koseluruhan & $\mathbf{7 3}$ & $\mathbf{2 , 9 9}$ & $\mathbf{1 , 0 5}$ & $\mathbf{1 1 , 1 9}$ & $\mathbf{1 , 6 8}$ & $\mathbf{0 , 6 3}$ & $\mathbf{0 , 1 3}$ \\
\hline (Pembelajaran & Tinggi & 12 & 3,42 & 0,67 & 10,92 & 0,60 & 0,60 & 0,15 \\
Biasa) & Sedang & 44 & 3,07 & 0,93 & 8,80 & 1,75 & 0,44 & 0,14 \\
& Rendah & 10 & 3,00 & 0,67 & 7,10 & 1,97 & 0,31 & 0,15 \\
& Keseluruhan & $\mathbf{6 6}$ & $\mathbf{3 , 1 2}$ & $\mathbf{0 , 8 5}$ & $\mathbf{8 , 9 2}$ & $\mathbf{2 , 1 1}$ & $\mathbf{0 , 4 5}$ & $\mathbf{0 , 1 6}$ \\
\hline
\end{tabular}

Skor Maksimum = 16

Tabel 2 memperlihatkan bahwa sebelum pembelajaran, skor rata-rata kompetensi strategis matematis siswa yang belajar menggunakan strategi team-based learning sebesar 2,99 kemudian skor rata-rata hasil postes sebesar 11,19. Berdasarkan nilai pretes dan postes tersebut, terdapat peningkatan sebesar 51,28\% dengan kualitas 0,63 yang termasuk dalam klasifikasi sedang, sedangkan kelas yang memperoleh pembelajaran biasa rata-rata kompetensi strategis matematis siswa pada pretes mencapai 3,12 dan rata-rata skor postes sebesar 8,92. Dengan demikian, peningkatan kompetensi strategis matematis sebesar 36,27\% dengan kualitas peningkatan 0,45 yang termasuk dalam klasifikasi sedang.

\section{Statistik Inferensial}

\section{a. Analisis Data $N$-Gain kompetensi strategis matematis}

\section{1) Uji normalitas distribusi}

Uji normalitas data $\mathrm{N}$-Gainkompetensi strategis matematis menggunakan uji statistik kolmogorov-smirnov dengan taraf signifikansi $\alpha=0,05$.

\section{Hipotesis}

$\mathrm{H}_{0}$ : dataN-Gainkompetensi strategis matematis berdistribusi normal

$\mathrm{H}_{1}$ : data $N$-Gainkompetensi strategis matematis berdistribusi tidak normal

\section{Kriteria pengujian}

Tolak $\mathrm{H}_{0}$ jika nilai probabilitas (sig.) $<\alpha=0,05$ dan terima $\mathrm{H}_{0}$ untuk lainnya.

Rangkuman hasil uji normalitas data $N$-Gainkompetensi strategis matematis disajikan pada Tabel 3.

Tabel 3

Hasil Uji Normalitas Data $N$-GainKompetensi Strategis Matematis

\begin{tabular}{cccccc}
\multirow{2}{*}{ Hasil } & \multirow{2}{*}{ Kelas } & \multicolumn{2}{c}{ Kolmogorov-Smirnov } & \multirow{2}{*}{ Kesimpulan } \\
& & Statistic & $d f$ & Sig & \\
\hline \multirow{2}{*}{$<\mathrm{g}\rangle$} & Eksperimen & 0,104 & 73 & 0,051 & Data berdistribusi normal \\
& Kontrol & 0,101 & 66 & 0,094 & Data berdistribusi normal \\
\hline
\end{tabular}


Berdasarkan perhitungan yang disajikan pada Tabel 3 di atas, terlihat bahwa nilai Sig. kelas eksperimen dan kelas kontrol lebih dari 0,05 sehingga hipotesis nol diterima. Artinya sampel penelitian berasal dari populasi yang berdistribusi normal, maka dilanjutkan dengan uji homogenitas.

\section{2) Uji homogenitas}

Uji homogenitas data $N$-Gain kompetensi strategis matematis matematis menggunakan tes Levene Statistic dengan taraf signifikansi $\alpha=0,05$.

\section{Hipotesis}

$$
\begin{aligned}
& \mathrm{H}_{0}: \sigma_{1}^{2}=\sigma_{2}^{2} \\
& \mathrm{H}_{1}: \sigma_{1}^{2} \neq \sigma_{2}^{2}
\end{aligned}
$$

Keterangan:

$\sigma_{1}^{2}$ : Variansi data $N$-Gain kompetensi strategis matematis kelas eksperimen

$\sigma_{2}^{2}$ : Variansi data $N$-Gain kompetensi strategis matematis kelas kontrol

\section{Kriteria Pengujian}

Tolak $\mathrm{H}_{0}$ jika nilai probabilitas (sig.) $<\alpha=0,05$ dan terima $\mathrm{H}_{0}$ untuk lainnya.

Rangkuman hasil uji homogenitas data $N$-Gain kompetensi strategis matematis disajikan pada Tabel 4.

\section{Tabel 4}

Uji Homogenitas Data $N$-GainKompetensi Strategis Matematis

\begin{tabular}{cccccc}
\hline Hasil & Levene Statistic & $d f 1$ & $d f 2$ & Sig. & Kesimpulan \\
\hline$\langle\mathrm{g}\rangle$ & 2,999 & 1 & 137 & 0,086 & Bervariansi homogen \\
\hline
\end{tabular}

Berdasarkan kriteria pengujian dan data pada Tabel 4, terlihat bahwa nilai $\operatorname{Sig}=0,086>0,05$ $=\alpha$ sehingga hipotesis nol diterima. Artinya variansi populasi data $N$-Gain kompetensi strategis matematis kelas eksperimen dan kelas kontrol homogen. Oleh karena kedua kelas homogen, maka dilanjutkan dengan uji t.

\section{3) Uji perbedaan data $\mathrm{N}$-Gain kompetensi strategis matematis}

"Peningkatan kompetensi strategis matematis siswa yang memperoleh pembelajaran dengan strategi team-based learning lebih tinggi secara signifikan dibandingkan dengan siswa yang memperoleh pembelajaran biasa."

\section{Hipotesis}

$$
\begin{aligned}
& \mathrm{H}_{0}: \mu_{\mathrm{kse}} \leq \mu_{\mathrm{ksk}} \\
& \mathrm{H}_{1}: \mu_{\mathrm{kse}}>\mu_{\mathrm{ksk}}
\end{aligned}
$$

\section{Keterangan:}

$\mu_{\text {kse }}$ : rata-rata data $N$-Gain kompetensi strategis matematis siswa yang memperoleh pembelajaran dengan strategi team-based learning (kelas eksperimen)

$\mu_{\text {ksk }}$ : rata-rata data $N$-Gain kompetensi strategis matematis siswa yang memperoleh pembelajaran biasa (kelas kontrol) 


\section{Kriteria pengujian}

Tolak $\mathrm{H}_{0}$ jika nilai probabilitas (sig.) $<\alpha=0,05$ dan terima $\mathrm{H}_{0}$ untuk lainnya.

Berikut rangkuman hasil uji perbedaan rata-rata data $N$-Gain kompetensi strategis matematis pada taraf signifikansi $\alpha=0,05$ disajikan pada Tabel 5 .

\section{Tabel 5}

Hasil Uji Perbedaan Rata-rata Data $N$-GainKompetensi Strategis Matematis

\begin{tabular}{cccc}
\hline \multicolumn{3}{c}{ t-test for Equality of Means } \\
(variances assumed) & Keterangan \\
$T$ & $D f$ & Sig. $(1$-tailed $)$ & \\
\hline 7,268 & 137 & 0,000 & $\mathrm{H}_{0}$ ditolak \\
\hline
\end{tabular}

Dari hasil uji independent samples t-test diperoleh nilai Sig. (1-tailed) yaitu $0,000<0,05=\alpha$. Hal ini menunjukkan bahwa $\mathrm{H}_{0}$ ditolak. Dengan demikian, dapat disimpulkan bahwa peningkatan kompetensi strategis matematis siswa yang memperoleh pembelajaran dengan strategi team-based learning lebih tinggi secara signifikan daripada siswa yang memperoleh pembelajaran biasa.

\section{b. Analisis peningkatan kompetensi strategis matematis berdasarkan PAM}

1) PAM kelompok tinggi

a) Uji normalitas distribusi

Uji normalitas data $N$-Gainkompetensi strategis matematis untuk kelompok tinggi menggunakan uji statistik kolmogorov-smirnov dengan taraf signifikansi $\alpha=0,05$.

\section{Hipotesis}

$\mathrm{H}_{0}$ : data $\mathrm{N}$-Gainkompetensi strategis matematiskelompok tinggi berdistribusi normal $\mathrm{H}_{1}$ : data $N$-Gainkompetensi strategis matematiskelompok tinggi tidak berdistribusi normal

\section{Kriteria pengujian}

Tolak $\mathrm{H}_{0}$ jika nilai probabilitas (sig.) $<\alpha=0,05$ dan terima $\mathrm{H}_{0}$ untuk lainnya.

Rangkuman hasil uji normalitas dataN-Gainkompetensi strategis matematis untuk kelompok tinggi disajikan pada Tabel 6.

Tabel 6

Hasil Uji Normalitas DataN-GainKompetensi Strategis Matematis (Tinggi)

\begin{tabular}{cccccc}
\multirow{2}{*}{ Hasil } & \multirow{2}{*}{ Kelas } & \multicolumn{2}{c}{ Kolmogorov-Smirnov } & \multirow{2}{*}{ Kesimpulan } \\
& & Statistic & Df & Sig & \\
\hline \multirow{2}{*}{$\langle\mathrm{g}\rangle$} & Eksperimen & 0,136 & 11 & $0,200^{*}$ & Data berdistribusi normal \\
& Kontrol & 0,187 & 12 & $0,200^{*}$ & Data berdistribusi normal \\
\hline
\end{tabular}

Berdasarkan perhitungan yang disajikan pada Tabel6 di atas, terlihat bahwa nilai Sig. kelas eksperimen dan kelas kontrol lebih dari 0,05 sehingga hipotesis nol diterima. Artinya sampel penelitian berasal dari populasi yang berdistribusi normal, maka dilanjutkan dengan uji homogenitas. 


\section{b) Uji homogenitas}

Uji homogenitas data $N$-Gainkompetensi strategis matematis kelompok tinggi menggunakan tes Levene Statistic dengan taraf signifikansi $\alpha=0,05$.

\section{Hipotesis}

$$
\begin{aligned}
& \mathrm{H}_{0}: \sigma_{1}^{2}=\sigma_{2}^{2} \\
& \mathrm{H}_{1}: \sigma_{1}^{2} \neq \sigma_{2}^{2}
\end{aligned}
$$

Keterangan:

$\sigma_{1}^{2}$ : Variansi data $\mathrm{N}$-Gain kompetensi strategis matematis kelas eksperimen kelompok tinggi

$\sigma_{2}^{2}$ : Variansi data $N$-Gain kompetensi strategis matematis kelas kontrol kelompok tinggi

\section{Kriteria Pengujian}

Tolak $\mathrm{H}_{0}$ jika nilai probabilitas (sig.) $<\alpha=0,05$ dan terima $\mathrm{H}_{0}$ untuk lainnya.

Rangkuman hasil uji homogenitas dataN-Gainkompetensi strategis matematis untuk kelompok tinggi disajikan pada Tabel 7.

\section{Tabel 7}

Uji Homogenitas DataN-Gain Kompetensi Strategis Matematis (Tinggi)

\begin{tabular}{cccccc}
\hline Hasil & Levene Statistic & $d f 1$ & $d f 2$ & Sig. & Kesimpulan \\
\hline$\langle\mathrm{g}\rangle$ & 0,280 & 1 & 21 & 0,602 & Bervariansi homogen \\
\hline
\end{tabular}

Berdasarkan kriteria pengujian dan data pada Tabel 7 di atas, terlihat bahwa nilai Sig = $0,602>0,05=\alpha$ sehingga hipotesis nol diterima. Artinya variansi populasi data $N$-Gain kompetensi strategis matematis kelas eksperimen dan kelas kontrol untuk kelompok tinggi homogen. Oleh karena kedua kelas homogen, maka dilanjutkan dengan uji t.

\section{c) Uji perbedaan skor $\mathbf{N}$-Gain kompetensi strategis matematis siswa kelompok tinggi}

"Peningkatan kompetensi strategis matematis siswa yang memperoleh pembelajaran dengan strategi team-based learninglebih tinggi secara signifikan daripada siswa yang memperoleh pembelajaran biasaditinjau dari kategori pengetahuan awal matematika untuk kelompok tinggi."

\section{Hipotesis}

$$
\begin{aligned}
& \mathrm{H}_{0}: \mu_{\mathrm{kset}} \leq \mu_{\mathrm{kskt}} \\
& \mathrm{H}_{1}: \mu_{\mathrm{kset}}>\mu_{\mathrm{kskt}}
\end{aligned}
$$

\section{Keterangan:}

$\mu_{\text {kset }}$ : rata-rata data $N$-Gain kompetensi strategis matematis siswa yang memperoleh pembelajaran dengan strategi team-based learning (kelas eksperimen) kelompok tinggi

$\mu_{\text {kskt: }}$ rata-rata data $N$-Gain kompetensi strategis matematis siswa yang memperoleh pembelajaran biasa (kelas kontrol) kelompok tinggi

\section{Kriteria pengujian}

Tolak $\mathrm{H}_{0}$ jika nilai probabilitas (sig.) $<\alpha=0,05$ dan terima $\mathrm{H}_{0}$ untuk lainnya. 
Berikut rangkuman hasil uji perbedaan rata-rata data $\mathrm{N}$-Gainkompetensi strategis matematis untuk kelompok tinggipada taraf signifikansi $\alpha=0,05$ disajikan pada Tabel 8 berikut.

\section{Tabel 8}

Hasil Uji Perbedaan Rata-rata DataN-GainKompetensi Strategis Matematis Kelompok Tinggi

\begin{tabular}{|c|c|c|c|}
\hline \multicolumn{3}{|c|}{ t-test for Equality of Means } & \multirow[t]{2}{*}{ Keterangan } \\
\hline$t$ & $d f$ & Sig. (1-tailed) & \\
\hline 0,713 & 21 & 0,242 & $\mathrm{H}_{0}$ diterima \\
\hline
\end{tabular}

Dari hasil uji independent sample t-test diperoleh nilai Sig. (1-tailed) yaitu 0,242 $>0,05=\alpha$. Hal ini menunjukkan bahwa $\mathrm{H}_{0}$ diterima. Dengan demikian, dapat disimpulkan bahwa peningkatan kompetensi strategis matematis siswa yang memperoleh pembelajaran dengan strategi team-based learningtidak lebih tinggi atau dapat dikatakan tidak terdapat perbedaan yang signifikan dengan siswa yang memperoleh pembelajaran biasa untuk kelompok tinggi.

\section{2) PAM kelompok sedang}

\section{a) Uji normalitas distribusi}

Uji normalitas data $N$-Gainkompetensi strategis matematis untuk kelompok sedang menggunakan uji statistik kolmogorov-smirnov dengan taraf signifikansi $\alpha=0,05$.

\section{Hipotesis}

$\mathrm{H}_{0}$ : data $N$-Gainkompetensi strategis matematiskelompok sedang berdistribusi normal

$\mathrm{H}_{1}$ : data $\mathrm{N}$-Gain kompetensi strategis matematiskelompok sedangberdistribusi tidak normal

\section{Kriteria pengujian}

Tolak $\mathrm{H}_{0}$ jika nilai probabilitas (sig.) $<\alpha=0,05$ dan terima $\mathrm{H}_{0}$ untuk lainnya.

Rangkuman hasil uji normalitas dataN-Gainkompetensi strategis matematis untuk kelompok sedang disajikan pada Tabel 9.

Tabel 9

Hasil Uji Normalitas DataN-GainKompetensi Strategis Matematis (Sedang)

\begin{tabular}{cccccc}
\multirow{2}{*}{ Hasil } & \multirow{2}{*}{ Kelas } & \multicolumn{3}{c}{ Kolmogorov-Smirnov } & \multirow{2}{*}{ Kesimpulan } \\
& & Statistic & Df & Sig & \\
\hline \multirow{2}{*}{$<\mathrm{g}\rangle$} & Eksperimen & 0,125 & 53 & 0,037 & Data tidak berdistribusi normal \\
& Kontrol & 0,104 & 44 & $0,200^{*}$ & Data berdistribusi normal \\
\hline
\end{tabular}

Berdasarkan perhitungan yang disajikan pada Tabel 9di atas, terlihat bahwa nilai Sig. kelas eksperimen kurang dari 0,05 sehingga hipotesis nol ditolak. Artinya sampel penelitian berasal dari populasi yangberdistribusi tidak normal, maka dilanjutkan dengan uji Mann-Whitney.

\section{b) Uji perbedaan dua rata-rata data $\mathrm{N}$-Gain kompetensi strategis matematis siswa} kelompok sedang

"Peningkatan kompetensi strategis matematis siswa yang memperoleh pembelajaran dengan strategi team-based learning lebih tinggi secara signifikan daripada siswa yang memperoleh pembelajaran biasa ditinjau dari pengetahuan awal matematika untuk kelompok sedang." 


\section{Hipotesis}

$$
\begin{aligned}
& \mathrm{H}_{0}: \mu_{\mathrm{R}_{\mathrm{kses}}} \leq \mu_{\mathrm{R}_{\mathrm{ksks}}} \\
& \mathrm{H}_{1}: \mu_{\mathrm{R}_{\mathrm{kses}}}>\mu_{\mathrm{R}_{\mathrm{ksks}}}
\end{aligned}
$$

Keterangan:

$\mu_{\mathrm{R}_{\mathrm{kses}}}$ : rata-rata rangking dataN-Gain kompetensi strategis matematis siswa yang memperoleh pembelajaran dengan strategi team-based learning (kelas eksperimen) kelompok sedang

$\mu_{\mathrm{R}_{\mathrm{ksks}}}$ : rata-rata rangking dataN-Gain kompetensi strategis matematis siswa yang memperoleh pembelajaran biasa (kelas kontrol) kelompok sedang

\section{Kriteria pengujian}

Tolak $\mathrm{H}_{0}$ jika nilai probabilitas ( $\mathrm{sig}$.) $<\alpha=0,05$ dan terima $\mathrm{H}_{0}$ untuk lainnya.

Berikut rangkuman hasil uji perbedaan rata-rata data $N$-Gain kompetensi strategis matematis untuk kelompok sedangpada taraf signifikansi $\alpha=0,05$.

\section{Tabel 10}

Hasil Uji Perbedaan Rata-rata DataN-GainKompetensi Strategis Matematis Kelompok Sedang

\begin{tabular}{cc}
\hline & SKOR \\
\hline Mann-Whitney $U$ & 372,000 \\
Wilcoxon $W$ & 1362,000 \\
$Z$ & $-5,766$ \\
Asymp. Sig (2-tailed) & 0,000 \\
\hline
\end{tabular}

Berdasarkan uji Mann-Whitney, diperoleh nilai Sig. $(1$-tailed $)=0,000<0,05=\alpha$. Hal ini menunjukkan bahwa $\mathrm{H}_{0}$ ditolak, artinya peningkatan kompetensi strategis matematis siswa yang memperoleh pembelajaran dengan strategi team-based learning lebih tinggi secara signifikan daripada siswa yang memperoleh pembelajaran biasa untuk kelompok sedang.

\section{3) PAM kelompok rendah}

\section{a) Uji normalitas distribusi}

Uji normalitas data $N$-Gainkompetensi strategis matematis untuk kelompok rendah menggunakan uji statistik kolmogorov-smirnov dengan taraf signifikansi $\alpha=0,05$.

\section{Hipotesis}

$\mathrm{H}_{0}$ : data $N$-Gainkompetensi strategis matematiskelompok rendah berdistribusi normal

$\mathrm{H}_{1}$ : data $\mathrm{N}$-Gainkompetensi strategis matematiskelompok rendah berdistribusi tidak normal

\section{Kriteria pengujian}

Tolak $\mathrm{H}_{0}$ jika nilai probabilitas (sig.) $<\alpha=0,05$ dan terima $\mathrm{H}_{0}$ untuk lainnya. 
Rangkuman hasil uji normalitas data $N$-Gain disajikan pada Tabel 11.

Tabel 11

Hasil Uji Normalitas DataN-GainKompetensi Strategis Matematis (Rendah)

\begin{tabular}{cccccc}
\multirow{2}{*}{ Hasil } & \multirow{2}{*}{ Kelas } & \multicolumn{3}{c}{ Kolmogorov-Smirnov } & \multirow{2}{*}{ Kesimpulan } \\
& & Statistic & Df & Sig & \\
\hline \multirow{2}{*}{$\langle\mathrm{g}\rangle$} & Eksperimen & 0,383 & 9 & 0,036 & Data berdistribusi tidak normal \\
& Kontrol & 0,216 & 10 & $0,200^{*}$ & Data berdistribusi normal \\
\hline
\end{tabular}

Berdasarkan perhitungan yang disajikan pada Tabel 4.11, terlihat bahwa nilai Sig. kelas eksperimen kurang dari 0,05 sehingga hipotesis nol ditolak. Artinya sampel penelitian berasal dari populasi yangberdistribusi tidak normal, maka dilanjutkan dengan uji Mann-Whitney.

\section{b) Uji perbedaan dua rata-rata dataN-Gain kompetensi strategis matematis siswa kelompok rendah}

Setelah diketahui bahwa dataN-Gain kompetensi strategis matematis untuk kelompok rendah berdistribusi tidak normal, maka dilanjutkan pada uji perbedaan rata-rata data $N$ Gainkompetensi strategis matematis untuk kelompok rendahdengan menggunakan uji statistik Mann-Whitney.

Hipotesis penelitian yang akan diuji adalah.

"Peningkatan kompetensi strategis matematis siswa yang memperoleh pembelajaran dengan strategi team-based learning lebih tinggi secara signifikan daripada siswa yang memperoleh pembelajaran biasa ditinjau dari pengetahuan awal matematika untuk kelompok rendah."

\section{Hipotesis}

$$
\begin{aligned}
& \mathrm{H}_{0}: \mu_{\mathrm{R}_{\mathrm{kser}}} \leq \mu_{\mathrm{R}_{\mathrm{kskr}}} \\
& \mathrm{H}_{1}: \mu_{\mathrm{R}_{\mathrm{kser}}}>\mu_{\mathrm{R}_{\mathrm{kskr}}}
\end{aligned}
$$

Keterangan:

$\mu_{\mathrm{R}_{\mathrm{kser}}}$ : rata-rata rangking data $\mathrm{N}$-Gain kompetensi strategis matematis siswa yang memperoleh pembelajaran dengan strategi team-based learning (kelas eksperimen) kelompok rendah

$\mu_{\mathrm{R}_{\mathrm{kskr}}}$ : rata-rata rangking dataN-Gain kompetensi strategis matematis siswa yang memperoleh pembelajaran biasa (kelas kontrol) kelompok rendah

\section{Kriteria pengujian}

Tolak $\mathrm{H}_{0}$ jika nilai probabilitas ( sig.) $<\alpha=0,05$ dan terima $\mathrm{H}_{0}$ untuk lainnya.

Rangkuman hasil uji perbedaan rata-rata dataN-Gain kompetensi strategis matematis untuk kelompok rendahpada taraf signifikansi $\alpha=0,05$ disajikan pada Tabel 12 .

Tabel 12

Hasil Uji Perbedaan Rata-rata DataN-GainKompetensi Strategis Matematis Kelompok Rendah

\begin{tabular}{cc}
\hline & SKOR \\
\hline Mann-Whitney $U$ & 7,000 \\
Wilcoxon $W$ & 62,000 \\
$Z$ & $-3,136$ \\
Asymp. Sig (2-tailed) & 0,002 \\
\hline
\end{tabular}


Berdasarkan uji Mann-Whitney, diperoleh nilai Sig. $(1$-tailed $)=0,001<0,05=\alpha$. Hal ini menunjukkan bahwa $\mathrm{H}_{0}$ ditolak, artinya peningkatan kompetensi strategis matematis siswa yang memperoleh pembelajaran dengan strategi team-based learning lebih tinggi secara signifikan daripada siswa yang memperoleh pembelajaran biasa untuk kelompok rendah.

\section{B. Pembahasan}

\section{Peningkatan Kompetensi Strategis Matematis Siswa}

Untuk mengetahui seberapa besar peningkatan kompetensi strategis matematis siswa antara kedua kelas, dilakukan uji perbedaan rata-rata untuk data $\mathrm{N}$-gain kompetensi strategis matematis siswa antara kelas eksperimen dan kelas kontrol dengan melakukan uji- $t$ dan mengambil taraf signifikansi $\alpha=0,05$. Hasil uji menyatakan bahwa peningkatan kompetensi strategis matematis pada kedua kelas berbeda secara signifikan. Temuan penelitian ini diperkuat dengan penelitian yang dilakukan oleh Samuelsson (2010) yang menyimpulkan bahwa metode pembelajaran yang berbeda, mempengaruhi kecakapan matematis salah satunya kompetensi strategis.

Berdasarkan uraian di atas, dapat disimpulkan bahwa peningkatan kompetensi strategis matematis siswa yang memperoleh pembelajaran dengan strategi team-based learning secara signifikan lebih baik dibandingkan dengan siswa yang memperoleh pembelajaran biasa. Hal ini menunjukkan bahwa pembelajaran dengan strategi team-based learning memiliki peran yang berarti dalam meningkatkan kompetensi strategis matematis siswa pada materi program linier. Sejalan dengan penelitian Yashe (2013) yang menemukan bahwa strategi team-based learning merupakan strategi yang efisien dan menstandari untuk memperoleh manfaat yang maksimum dari siswa khususnya kelas besar.

\section{Peningkatan Kompetensi Strategis Matematis Siswa Berdasarkan PAM}

Ditinjau dari faktor kategori PAM tinggi, sedang dan rendah, hasil uji perbedaan rata-rata skor $N$-gain kompetensi strategis matematis antara siswa di kelas eksperimen dan kelas kontrol untuk kelompok tinggi menunjukkantidak terdapat perbedaan yang signifikan, dengan nilai probabilitas hasil uji tsebesar 0,483 lebih dari 0,05. Berdasarkan uji Mann-Whitney untuk kelompok sedang dan rendah, hasil pengujian menunjukkan bahwa terdapat perbedaan yang signifikan dengan nilai probabilitas kurang dari 0,05. Dengan kata lain, peningkatan kompetensi strategis matematis siswa yang memperoleh pembelajaran dengan strategi teambased learning lebih baik daripada siswa yang memperoleh pembelajaran biasa untuk kelompok sedang dan rendah.

Berdasarkan hasil penelitian yang dilakukan, dapat disimpulkan bahwa strategi team-based learning lebih sesuai diterapkan pada siswa yang memiliki kemampuan sedang dan rendah. Pada saat pembelajaran berlangsung dalam sebuah tim, siswa berkemampuan rendah dapat lebih terlibat secara aktif dalam diskusi kelompok. Hal ini diduga oleh rasa segan yang dimiliki siswa pada saat bertanya terhadap anggota tim lainnya lebih sedikit daripada saat bertanya terhadap guru. Selain itu, siswa berkemampuan tinggi akan merasa lebih bertanggung jawab atas berhasil tidaknya sebuah tim sehingga mereka akan lebih termotivasi untuk menjelaskan topik yang mereka pahami terhadap siswa berkemampuan sedang dan rendah. 
Hal ini sejalan dengan unsur dasar dari strategi team-based learning yaitu tim, yang harus berhasil dilaksanakan. Siswa berkemampuan tinggi akan menguji pemahaman mereka atas suatu topik ketika mereka menjelaskan topik tersebut kepada siswa berkemampuan sedang dan rendah dalam tim mereka selama kegiatan berlangsung.

\section{KESIMPULAN, IMPLIKASI DAN REKOMENDASI}

Berdasarkan hasil penelitian dan pembahasan, peningkatan kompetensi strategis matematis siswa yang memperoleh pembelajaran dengan strategi team-based learning lebih tinggi daripada siswa yang memperoleh pembelajaran biasa ditinjau dari keseluruhan siswa dan untuk kategori pengetahuan awal matematika sedang dan rendah.

\section{DAFTAR PUSTAKA}

Arends, R. I. 2008. Learning to Teach. (edisi ketujuh). Buku 1. Alih Bahasa: Helly P. S dan Sri M. S. Yogyakarta: Pustaka Pelajar.

Kilpatrick, J., et.al. 2001. Adding It Up: Helping Children Learn Mathematics. Washington, D.C.: National Academy Press.

Michaelsen, L.K. \& Sweet, M. 2008. The Essential Elements of Team-Based Learning. New Directions for Teaching and Learning, Number 116. Jossey-Bass. [Online]. Diakses dari http://www-dev.csusm.edu/iits/ids/ documents/active-learning/active\%20 learning/Team-based\%20Learning\% 20michaelsen.pdf. [28 Januari 2014]

Samuelsson, J. 2010. The Impact of Teaching Approaches on Students' Mathematical Proficiency in Sweden. International Electronic Journal of Mathematics Education, Volume 5 Nomor 2: ISSN 1306-3030. [Online]. Diakses dari http://iejme.com/022010/d2.pdf.[28 Januari 2014].

Yashe, A., et.al. 2013. Observable Effects of Developing Mathematical Skills of Students through Team- Based Learning and Laboratory Learning Approaches. Journal of Education and Practice, Volume 4 Nomor 2, hlm. 189-191, ISSN 2222-1735 (Paper) ISSN 2222-288X (Online). [Online]. Diakses dari: http://www..iiste.org [28 Januari 2014]. 